\title{
Merkel Cell Carcinoma pNX TNM Finding v7
}

National Cancer Institute

\section{Source}

National Cancer Institute. Merkel Cell Carcinoma pNX TNM Finding v7. NCI Thesaurus.

Code C88526.

Merkel cell carcinoma in which the regional lymph nodes cannot be assessed. (from AJCC 7th Ed.) 